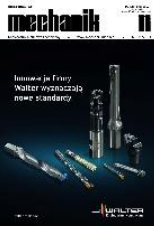

How to cite this article:

Authors: Wojciech Borkowski, Piotr Cichosz, Mateusz Pudłowski, Hubert Skowronek, Kamil Waszczuk

Title of article: „Influence of changes in machinability of nodular cast iron on manufacturing costs”

Mechanik, No. 11 (2019)

DOI: https://doi.org/10.17814/mechanik.2019.11.99

\title{
Influence of changes in machinability of nodular cast iron on manufacturing costs
}

\author{
WOJCIECH BORKOWSKI \\ PIOTR CICHOSZ \\ MATEUSZ PUDŁOWSKI \\ HUBERT SKOWRONEK \\ KAMIL WASZCZUK*
}
* Mgr inż. Wojciech Borkowski, wojciech.borkowski@pwr.edu.pl, https://orcid.org/0000-0001-5906-0874 - Katedra Obrabiarek i
Technologii Mechanicznych, Wydział Mechaniczny, Politechnika Wrocławska, Wrocław, Polska
Prof. dr hab. inż. Piotr Cichosz, piotr.cichosz@pwr.edu.pl, https://orcid.org/0000-0002-1636-1973 - Katedra Obrabiarek i Technolo- gii Mechanicznych, Wydział Mechaniczny, Politechnika Wrocławska, Wrocław, Polska
Mgr inż. Mateusz Pudłowski, mpudlowski@guehring.pl - Gühring Sp. z o.o., Dąbrowa Górnicza, Polska
Dr inż. Hubert Skowronek, hubert.skowronek@pwr.edu.pl, https://orcid.org/0000-0003-3398-1661 - Katedra Obrabiarek i Techno- logii Mechanicznych, Wydział Mechaniczny, Politechnika Wrocławska, Wrocław, Polska,
Dr inż. Kamil Waszczuk, kamil.waszczuk@pwr.edu.pl, https://orcid.org/0000-0002-7889-4847 - Katedra Obrabiarek i Technologii Mechanicznych, Wydział Mechaniczny, Politechnika Wrocławska, Wrocław, Polska

Attempts to explain changes in the efficiency of nodular cast iron machining caused by the dispersion of its mechanical properties affecting on the intensity of tools wear (such as VHM drills) have been presented. It has been also assessed to what extent changes in mechanical properties of tools, within the limits of the standards, can change the machining efficiency in quite intensive machining conditions of the automotive industry.

KEYWORDS: machinability, nodular cast iron, drilling, costs

\section{Introduction}

Spheroidal cast iron has a very good strength and plastic properties. Moreover, it can be easily shaped by casting methods. Therefore, it is widely used in mass production, e.g. in the automotive industry. It is used to perform, among other: crankshafts, camshafts, connecting rods, steering system components or gears. One of the shortcomings of this material is bad machinability $[1,6,7,9,10,13]$.

Material machinability has a crucial role in the products manufacturing. It affects not only the quality of manufactured elements, but - just as important - machining efficiency. A more detailed discussion of machinability is presented e.g. in publication [7]. In synthesis, it can be considered that the machinability depends on many factors, which include its physicochemical properties, including surface structure, type and machining method. Machinability is also closely related to: cutting properties of tool materials and protective coatings, blade geometry, including chip breaker, cutting support with cooling/heating and cutting zone lubrication, vibration cutting, trochoidal machining technologies, and also with technical condition and dynamic properties of the OUPN system.

The main task of production is to make a product of the assumed quality, in the most efficient way, usually as cheaply as possible or the most efficient, and occasionally in a way that is a combination of these demands.

The same blank material, according to standard, even declared by the same manufacturer, as a result of changes in the blank manufacturing technology may be easier or more difficult to machining. The aim of this study was to present the impact of changes in the ductile cast iron properties on the drills durability and the machining efficiency in intensive mass production conditions.

\section{Workpiece}

During testing, they had used ductile cast iron (works norm [11]) corresponding to grade EN-GJS 500-7. Its chemical composition according to standard and from two blanks A and B deliveries are shown in the table. 
TABLE. Chemical composition of ductile iron GGG55 according to standard [11] and supplied lots A and $B$ of this material

\begin{tabular}{|l|c|c|c|}
\cline { 2 - 4 } \multicolumn{1}{c|}{} & Norm[11] & A & B \\
\hline Fe [\%] & rest & 93.98 & 93.75 \\
\hline $\mathrm{C}[\%]$ & $3.2 \div 3.8$ & 3.20 & 3.24 \\
\hline $\mathrm{Si}[\%]$ & $2.2 \div 3.1$ & 2.239 & 2.277 \\
\hline $\mathrm{Mn}[\%]$ & $0.1 \div 0.3$ & 0.248 & 0.280 \\
\hline $\mathrm{Cr}[\%]$ & - & 0.027 & 0.041 \\
\hline $\mathrm{Cu}[\%]$ & $0.20 \div 0.55$ & 0.232 & 0.266 \\
\hline $\mathrm{P}[\%]$ & $0 \div 0.05$ & 0.014 & 0.015 \\
\hline $\mathrm{S}[\%]$ & $0 \div 0.03$ & 0.003 & 0.002 \\
\hline $\mathrm{Ti}[\%]$ & - & 0.027 & 0.027 \\
\hline
\end{tabular}

This data shows that both parties - A and B blank deliveries were made of cast iron with chemical composition according to the standard.

Metallographic test of microstructure revealed relevant morphological differences (rys.1), especially in the surface layer that is being machined.

A hardness test was carried out by hardness testing Struers DuneJet. The measurements were performed on 16 samples front surfaces, where the holes were drilled. Test results are shown in fig. 2.
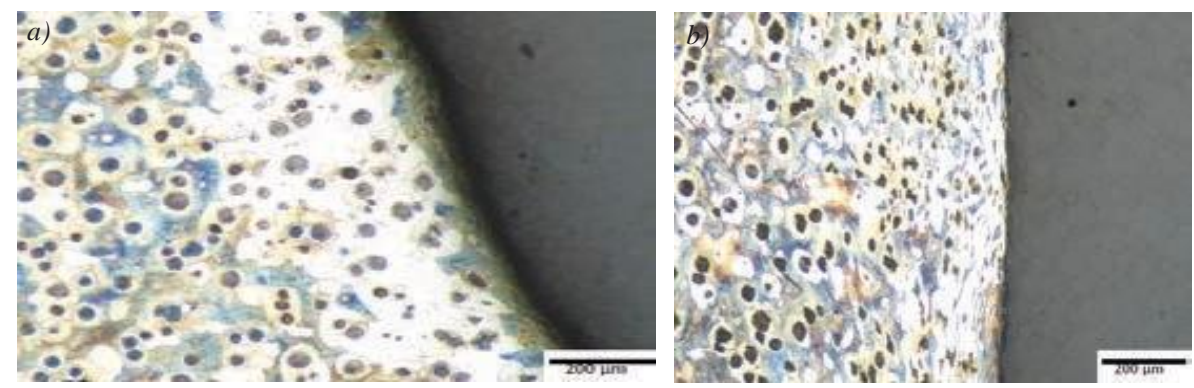

Fig. 1. Microstructure of the surface area: $a$ ) samples $A$ and $b$ ) samples $B$, enlargement $\times 100$, digested with nital

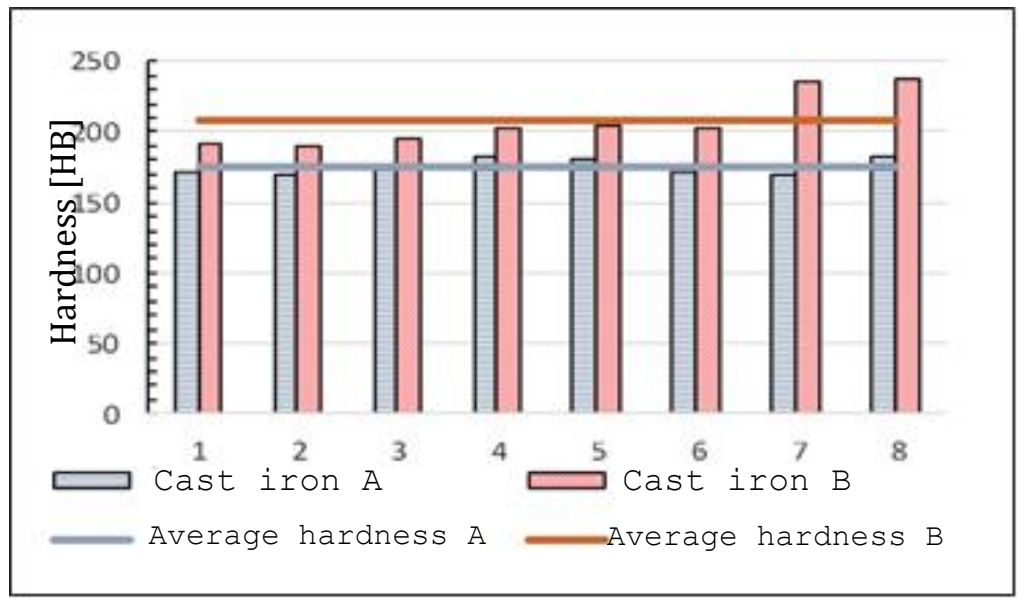

Fig. 2. Comparison of hardness of $A$ and $B$ ductile iron samples

It was fund that average hardness of cast iron A is 175,5 HB, and cast iron B 207,8 HB. The difference in hardness values was $18,4 \%$ and at the level $\alpha=0,05$ has proven to be an important. Standard deviation of cast iron A hardness is $S_{\mathrm{d}}=5,1 \mathrm{HB}$, and cast iron B $S_{\mathrm{d}}=18,8 \mathrm{HB}$, is almost four times higher. More significant dispersion has an impact on faster tools wear during machining of harder blanks and does not have to be appropriately compensated by the reduced wear during machining of harder ones. This impact intensification of the factors on the dependent variable - in this case, durability - is underscored in very intensive process conditions, which were used during drilling. 


\section{Cast iron machinability}

Machinability can be determined by relative or absolute indicators. In the case of relative indicators, the machinability of given material is compared with machinability of reference material. For such comparisons can be used e.g. periodic cutting speed or surface roughness. The first of these indicators is usually difficult and labor-intensive to use, therefore it can be replaced, e.g. with the durability or blade wear intensity. Simply: auxiliary indicators can be used, e.g. mechanical properties of the processed material, components of total cutting forces, cutting temperature or chips type. The mentioned auxiliary indicators may lead to decisions that are not entirely right, it is rarely the case that, e.g., an increase in the material hardness indicator by $10 \%$ will result in a proportional increase in tool costs.

To compare the machinability, followed by the costs and time of drilling holes in ductile iron products from two supplies lots ( $A$ and $B$ ), the following assumptions and test conditions were adopted:

- machining was carried out on machine tools HAAS VF-3YT,

- drill holes with diameter $d=18 \mathrm{~mm}$ and length $L=$

$40 \mathrm{~mm}$ in cylindrical sample with diameter $D=30 \mathrm{~mm}$,

- the tool was solid carbide drill type RT100S with a multi-layer coating PVD-TiN/TiAlN (company

Gühring),

- stand work cost was $K_{\mathrm{m}}=100 \mathrm{zt} / \mathrm{h}$,

- worker remuneration was $17 \mathrm{zt} / \mathrm{h}$,

- tool costs $K_{\mathrm{N}}=900 \mathrm{zt}$,

- the technological criterion of tool dulling was adopted, which was the loss of acceptable dimensional

- shaped accuracy of finished hole,

- regeneration cost (sharpening and re-coating) $K_{\mathrm{R}}=100 \mathrm{zł}$,

- tool exchange time after regeneration $t_{\mathrm{wn}}=4 \mathrm{~min}$,

- number of possible drill regenerations 6 ,

- machining conditions: $v_{\mathrm{c}}=125 \mathrm{~m} / \mathrm{min}, f=0,27 \mathrm{~mm} / \mathrm{rev}$ internal cooling with emulsion (in a concentration $6 \%$ ) under pressure $p=6,9 \mathrm{MPa}$.

The machinability tests with drilling of both cast iron supplies was carried out in real industrial conditions of mass production in the automotive industry plant. The first determined machinability indicator was tool durability $T_{\mathcal{c}}$, expressed by number of machined holes. Durability average values had been assessed during three months, during which aprox. 220 thousands holes were machined, consuming aprox. 270 drills. For materials $A$ and B the durability was respectively: $T_{\mathrm{cA}}=1100$ and $T_{\mathrm{cB}}=660 \mathrm{pcs}$. This difference $(40 \%)$ at significance level $\alpha=0,05$ has proven to be statistically significant.

The reduced drill durability caused an increase the need for tools and more frequent production line downtime for their replacement. This must increase machining costs and reduce its capacity. It was necessary to consider the main reasons for this state of affairs, and in particular the increased drill wear intensity. It was decided to examine other auxiliary machinability indicators, so: drilling force and moment, cutting temperature, type of arising chips and roughness after machining.

\section{Experimental tests results}

The results of comparative experimental tests of machinability indicators of materials A and B are presented in the aggregate graph (fig. 3) and described as percentage values of indicators for material B in relation to material A.

Forces measurements and cutting moments was carried out by four-piece piezoelectric dynamometer 9273 from Kistler working with multi-channel signal amplifier 5011 from Kistler.

It was established that the average axial force $F_{\mathrm{f}}$ during cast iron A drilling was $2127 \mathrm{~N}$, and cast iron B $2378 \mathrm{~N}$. The difference of average values was $11,8 \%$ and was statistically significant. Axial force standard deviation of both cast iron was almost identical and around approx. $73 \mathrm{~N}$. In the case of cast iron A machining cutting moment was $M_{\mathrm{c}}=29,75 \mathrm{Nm}$, but in the case of cast iron B $M_{\mathrm{c}}=35,75 \mathrm{Nm}$, which translated in a difference $20,2 \%$.

The objective of cutting temperature measurements was not to determine the actual maximum temperature that exist in the contact zone of the blade with the workpiece, but only to examine the temperature differences, which can be observed during both cast irons machining. To determine the actual temperature, very complex testing methods should be used, including the need to calibrate the blade surface emissivity, which depends on many factors (surface roughness, type of coating material, temperature, etc.), as well as the use of very fast thermal cameras or pyrometers for recording temperature on a selected, identified fragment of a drill, which is rotating with high speed. In addition, this would require samples and tools preparation.

It would be extremely time-consuming and expensive, it would involve disproportionate effort towards this 
objective, the comparation of the material machinability with similar properties.

The temperature of the drill at the moment of its exit from the material was compared. Sample thermal image recording with marked point $\mathrm{Sp} 1$, in which the tool temperature was read is shown in fig. 4. The tests tried to carried out in repeatable conditions, for both assessed materials, during dry drilling. Drill surface emissivity was $\varepsilon=0,9$.

The tool temperature thus determined is not the highest temperature, but only its average value. Temperature measurements were carried out by thermal camera FLIR model p620, which was located at 2 m distance form measured object.

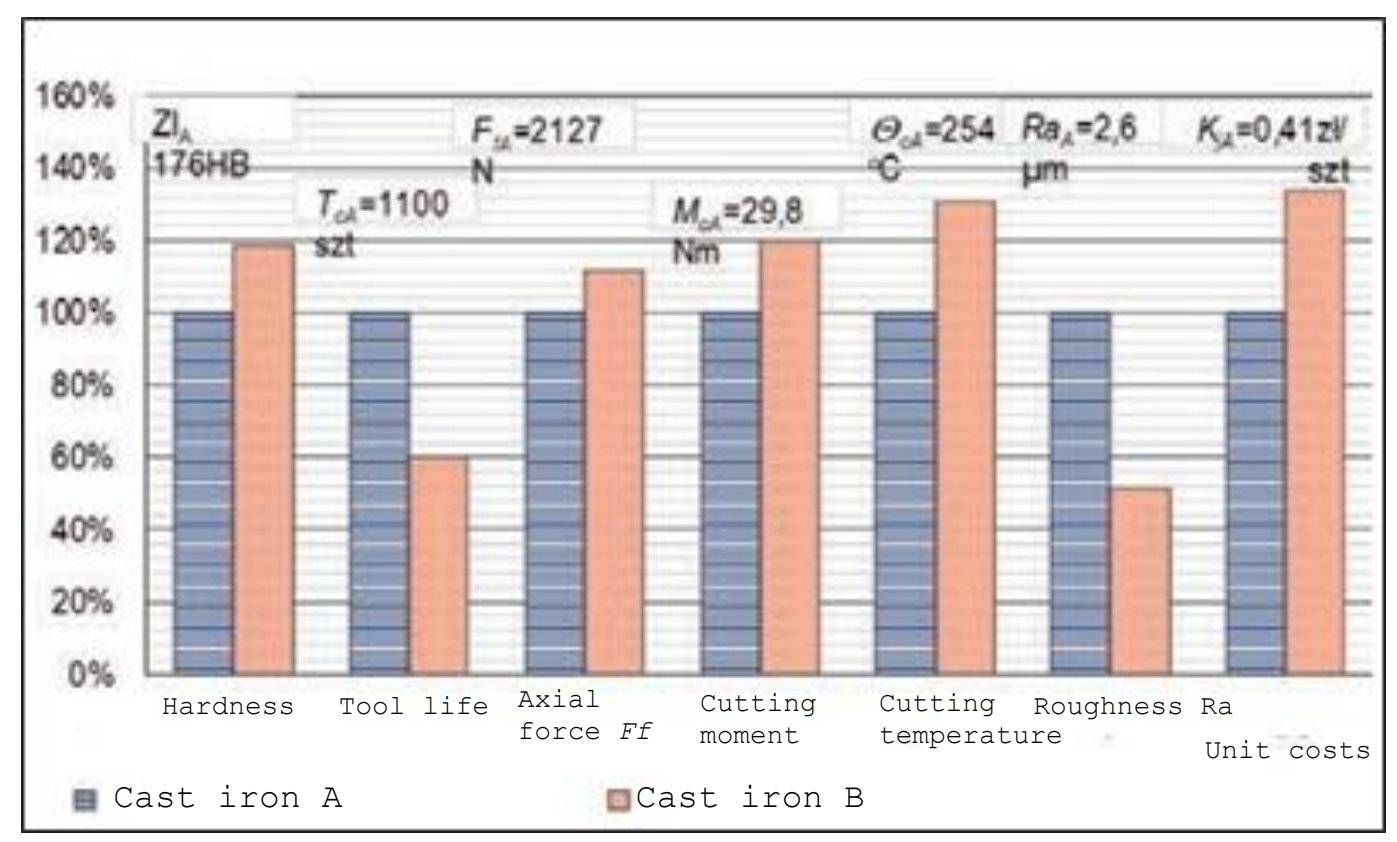

Fig. 3. Comparison of selected machinability indicators

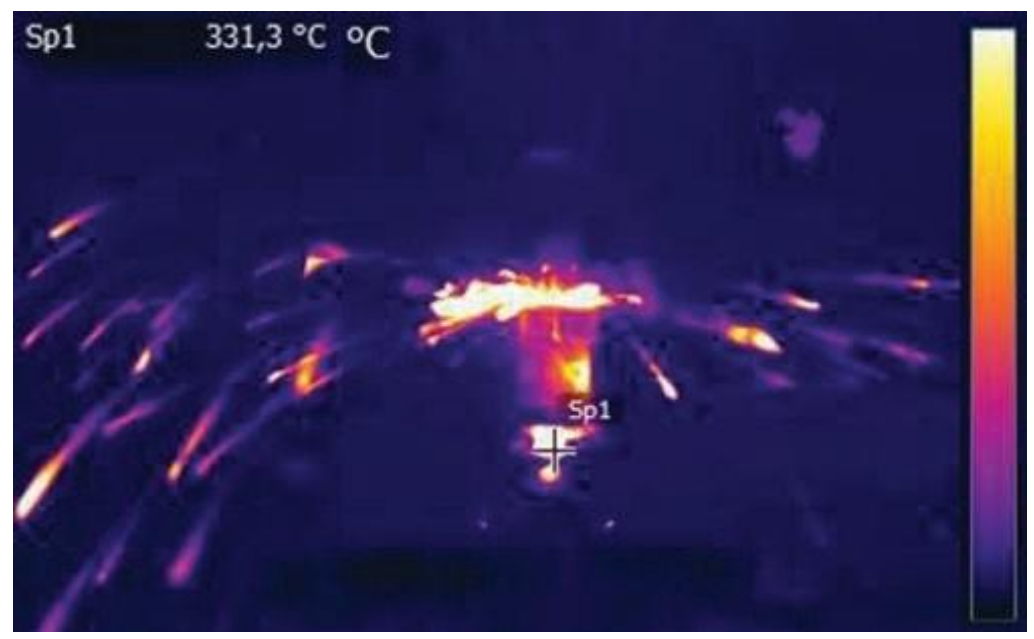

Fig. 4. Picture from a thermal imaging camera with the drill temperature point marked 
a)

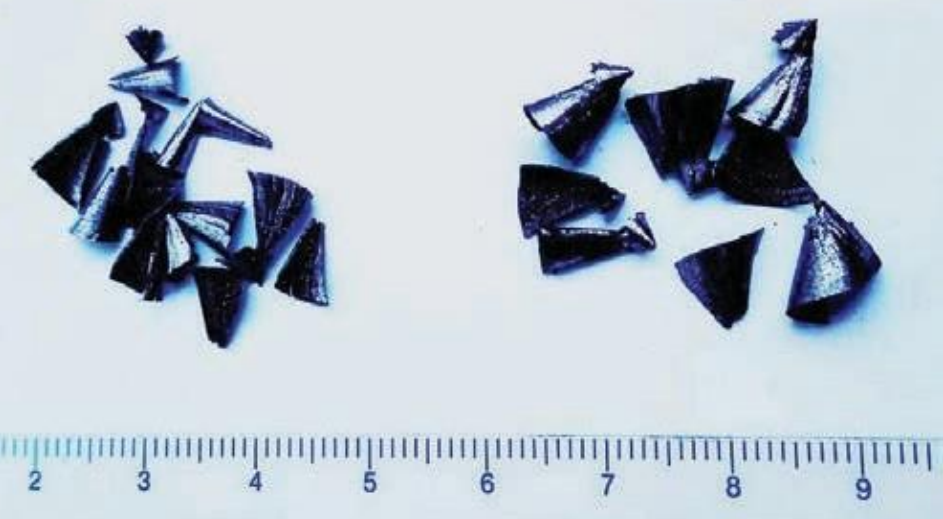

Fig. 5. Chips formed during drilling: $a$ ) cast iron $A, b$ ) cast iron $B$

The temperature of the working part of the drill during drilling of cast iron A was $254,3^{\circ} \mathrm{C}$, and in the case of cast iron B was $332,2^{\circ} \mathrm{C}$. The difference $(30,6 \%)$ was statistically significant. Such a large temperature difference, despite the differences in the hardness of both cast irons made up just $18.4 \%$, probably resulted from the fact that the tools worked in very intensive conditions.

The next indicators assessed were chip design and shape. Chips had the typical form, which is obtained during ductile irons drilling (fig. 5). According to PN-ISO 3686 can be classified a loose curved marked 6.2. There were no significant differences in the chip structure of both tested cast irons.

The roughness of the holes drilled in the material A and B differed significantly. For the material B parameter $R a$ value was lower about $49 \%$ compared with the material A.

\section{Costs and time of drilling operation}

Costs and unit machininig time were calculated according to the methodology presented in the publication [5] and sheet attached to it Kalkulacja kosztów i czasu operacji. xls. (Costs and operation time calculation). It noted that that as a result of the material batch change from $\mathrm{A}$ to $\mathrm{B}$, increased the drilling costs from $K_{\mathrm{jA}}=0,41$ $\mathrm{zt} / \mathrm{szt}$. to $K_{\mathrm{jB}}=0,55 \mathrm{zł} / \mathrm{szt}$. (by 34\%) and the machining time has increased from $t_{\mathrm{jA}}=0,1066 \mathrm{~min}$ to $t_{\mathrm{jB}}=0,1093$ min (almost by 2,6\%). Tool costs increased correspondingly by $66 \%$. In relation to the costs calculated for the whole series of products, which was performed during aprox. three months, it can be seen that globally the machining costs $K_{\text {serii }}$ increased by $30924 \mathrm{zł}$, and tools costs $K_{\mathrm{N}}$ by $29734 \mathrm{zł}$. These are large sums.

Based on the given data, the simulation has been carried out in order to determine how the costs and drilling time will change for a wider range of hypothetically changing tool durability, e.g. as a result of changes workpiece material properties. The results of these analyses are shown in fig. 6.

It can be seen that change the cutting properties of material, resulting in changes of tool durability, impact on tool costs $K_{\mathrm{N}}$, has a huge impact on tool costs $K_{\mathrm{N}}$, and almost half as much on machining costs $K_{j}$. This results, e.g., from the direct translating of changes in the tool durability to their number necessary to performe a production series. The machining costs function still has a component related to the work stand costs, employee remuneration and machining time, and therefore the change of the tools number has a lower impact on the total manufacturing costs $\Sigma K_{j}$. 


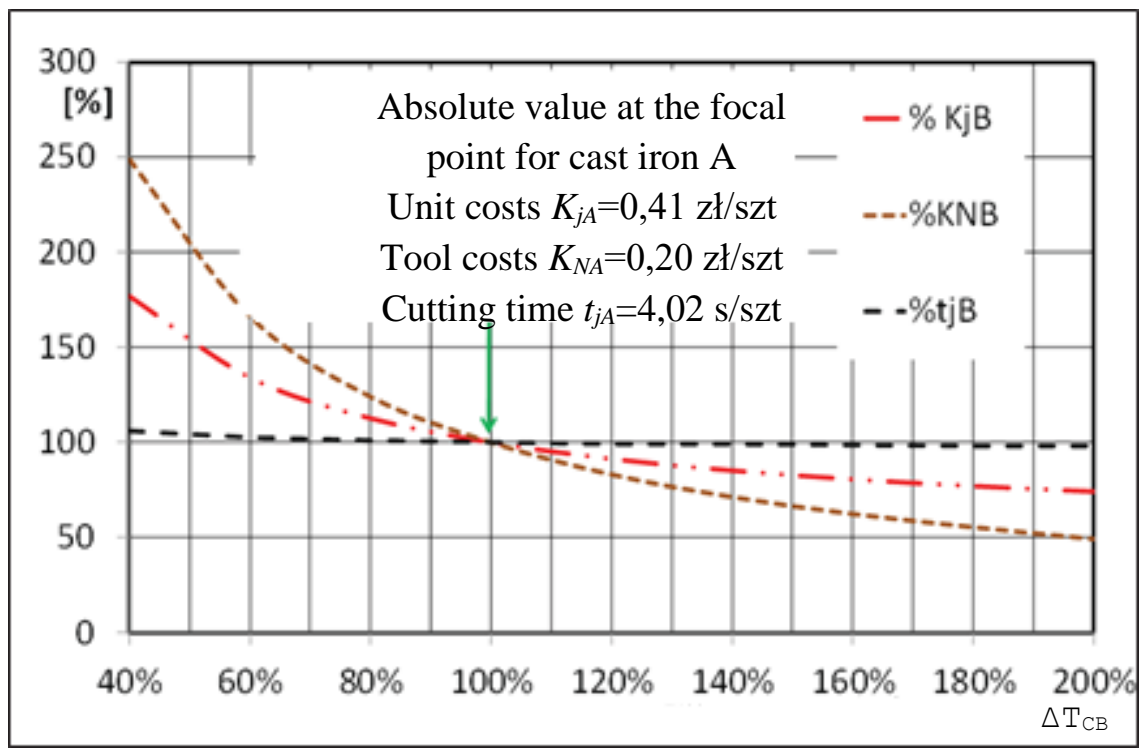

Fig. 6. Changes in machining costs $K_{\mathrm{j}}$, tool costs $K_{\mathrm{N}}$ and unit time $t_{\mathrm{j}}$ caused by a change in tool life $T_{\mathrm{CB}}$

If cutting parameters are not amended, the impact of tool wear changes for processing time is not significant. Temporary performance does not change. Only the time associated with the machine tools downtime necessary for tool change will be shortened or extended. However, in the case of long tool life, required in high-performance, automated production systems, this impact is small.

It is also worth noting that economic results changes, shown in fig. 6, in relation to durability, haven't linear correlation, but they are reversely proportional. This means that shortening tool durability, e.g. by $50 \%$, will increase tool costs by $100 \%$, while the same extension of tool durability will reduce tool costs by only approx. $50 \%$.

It is worth noting that in production facilities, as a result of a significant deterioration in the machinability of the material, it may be necessary to reduce machining parameters to extend tool durability and reduce tool costs. However, due to the increase of machining time, the other cost related to the process are increasing. Before making such a decision, it is necessary to calculate whether it is cost-effective.

\section{Summary}

The research shows that change of material properties, even the same type of material, e.g. nodular cast iron could firmly affects cutting tools wear intensity.

It may significantly change the manufacturing costs, in particular tools costs. If cutting parameters are not amended, the impact for processing time is not significant.

The data and change correlation of analyzed factors mentioned in this article, taken from the actual production facilities, apply only to these conditions and cannot be uncritically transferred to the analysis of other machining operations. The tendencies presented will have a similar trend, but the adopted decisions in every case should be preceded by an analysis and calculations adapted to the current data.

In large production facilities usually tool management is given to an external auditor, negotiating service costs for performance of specific batches [3]. It happens that the agreed cost of such service may be subject to variation due to the changes in the blank material properties affecting the tool wear intensity. All of this may considerably change machining efficiency. This may require renegotiation of the terms of the outsourcing agreement. The attention should be focused on such eventuality and ensure that the relevant records are introduced in the contract.

Analysis of obtained study results selected coefficient machinability during cast iron GGG55 drilling form two different blank $\mathrm{A}$ and $\mathrm{B}$ deliveries allow for the conclusion that in case of the change the material $\mathrm{A}$ to harder about $18,5 \%$ material $\mathrm{B}$ :

- there was a significant (up to $40 \%$ ) durability decrease of solid drills,

- axial forces $F_{\mathrm{f}}$ increased by approx. $11,8 \%$, and cutting torque $M_{\mathrm{c}} 20,2 \%$,

- drill temperature at the hole increased from 254,3 to $332,2^{\circ} \mathrm{C}$ (about $30,6 \%$ ),

- design and shape of chips have not changed,

- surface roughness of drilled holes expressed as parameter $R a$ has improved $49 \%$,

- drilling operations unit costs $K_{\mathrm{j}}$ has been extended from 0,41 to $0,55 \mathrm{zt} / \mathrm{pcs}$. (34\%),

- processing time $t_{\mathrm{j}}$ has been extended from 0,107 to $0,11 \mathrm{~min} / \mathrm{pcs}$. (which represented only 2,6\%). 


\section{REFERENCES}

[1] Benedetti M., Fontanari V., Lusuardi D. „Effect of graphite morphology on the fatigue and fracture resistance of ferritic ductile cast iron". Engineering Fracture Mechanics. 206 (2019): 427-441, https://doi.org/10.1016/j.engfracmech.2018.12.019.

[2] Cichosz P. „Efektywność kształtowania przedmiotów osiowosymetrycznych w zintegrowanym wytwarzaniu”. Wrocław: Oficyna Wyd. PWr, 1998: 31-57.

[3] Cichosz P., Subbotko R. „Gospodarka narzędziowa”. Mechanik. 10, 90 (2016): 1340-1343, http://dx.doi.org/10.17814/mechanik.2016.10.352.

[4] Cichosz P. „Ekonomiczne aspekty doboru narzędzi skrawających do zadania produkcyjnego”. Mechanik. 10, 11, 77 (2004): 642-647.

[5] Cichosz P. et. al. „Wybrane aspekty projektowania i wdrażania specjalnych narzędzi skrawających”. Prace Naukowe ITMiA PWr. Wrocław: Oficyna Wydawnicza PWr, 2012: 111-122.

[6] Ghani A.K., Choudhury I.A. "Study of tool life, surface roughness and vibration in machining nodular cast iron with ceramic tool". Journal of Materials Processing Technology. 127 (2002): 17-022.

[7] Grzesik W. „Podstawy skrawania materiałów konstrukcyjnych”. Warszawa: WNT, 2010: 349-372.

[8] Grzesik W., Kiszka P., Kowalczyk D., Rech J., Claudin Ch. „Machining of nodular cast iron (PF-NCI) using CBN tools". Procedia CIRP. 1 (2012): 483-487.

[9] Kowalczyk D., Grzesik W. „Badania tarcia i zużycia ostrzy z CBN w obróbce żeliwa sferoidalnego”. Obróbka skrawaniem - Efektywne wytwarzanie. Wrocław: Wydawnictwo ITMiA Politechniki Wrocławskiej, 2012: 143150.

[10] Kowalczyk D., Kiszka P., Grzesik W., Żak K. „Zużycie ostrza w toczeniu żeliwa sferoidalnego ostrzami z ceramiki azotowej i jego wpływ na przebieg procesu skrawania". Kruszyński B. (red.) Obróbka skrawaniem Współczesne problemy. Łódź: Agencja MALAGA, 2010: 183-190.

[11] Materiały informacyjne firmy Gühring.

[12] PN-EN 1563:2018, Odlewnictwo - Żeliwo sferoidalne.

[13] Yigit R., Celik R., Findik F., Koksal S. "Tool life performance of multilayer hard coatings produced by HTCVD for machining of nodular cast iron". International Journal of Refractory Metals \& Hard Materials. 26 (2008): 514-524, https://doi.org/10.1016/j.ijrmhm.2007.12.003 